\title{
Acute kidney injury in children with sickle cell disease-compounding a chronic problem
}

\author{
Cherry Mammen $^{1,2} \cdot$ Mei Lin Bissonnette ${ }^{3}$ Douglas G. Matsell ${ }^{1,2}$
}

Received: 5 March 2017 / Accepted: 10 March 2017 /Published online: 28 March 2017

(C) IPNA 2017

\begin{abstract}
In an article recently published in Pediatric Nephrology, Baddam and colleagues discuss the relatively underreported clinical problem of repeated episodes of acute kidney injury (AKI) in children with sickle cell disease (SCD). Their report is a cautionary note about the importance of repeated kidney injury on the background of underlying chronic kidney injury and its potential implications on long-term kidney outcome. In children and adults with SCD, this includes the effects of repeated vaso-occlusive crises and the management of these painful episodes with non-steroidal anti-inflammatory drugs. Here we review the scope of kidney involvement in SCD in children and discuss the potential short- and long-term consequences of AKI in children with SCD.
\end{abstract}

Keywords Sickle cell nephropathy · Vaso-occlusive pain crisis $\cdot$ Acute kidney injury $\cdot$ Non-steroidal anti-inflammatory drugs $\cdot$ Children

Douglas G. Matsell

dmatsell@cw.bc.ca

1 Department of Pediatrics, University of British Columbia, Vancouver, Canada

2 Division of Nephrology, British Columbia Children's Hospital, Vancouver, Canada

3 Department of Pathology and Laboratory Medicine, University of British Columbia, Vancouver, Canada

\section{Introduction}

In an article recently published in Pediatric Nephrology, Baddam and colleagues report an acute kidney injury (AKI) incidence of $17 \%$ in children with sickle cell disease (SCD) presenting to the hospital emergency room with vasoocclusive crisis, of whom 50\% developed AKI after being admitted to hospital [1]. In another recently published study, the same research group reported an incidence of AKI of $8 \%$ in children with SCD presenting with acute chest syndrome (ACS), characterized by fever and pulmonary infiltrates [2]. As highlighted by the authors in both reports, this kidney injury appears to be an underreported problem in this pediatric patient population. In adults, AKI occurs in 4-10\% of SCD patients who have been hospitalized, and in up to $14 \%$ of adults with ACS $[3,4]$. This high incidence of AKI, however, should not be surprising, given the underlying renal pathology in children with $\mathrm{SCD}$, the effects of vaso-occlusive crisis on this kidney background, and the continued use of non-steroidal anti-inflammatory drugs (NSAIDs) to treat painful crises in this patient population. We present a suggested paradigm of the pathway towards sickle cell nephropathy that includes the potential independent effects of single or repeated episodes of AKI (see Fig. 1).

\section{Sickle cell nephropathy}

Sickle cell nephropathy refers to the spectrum of chronic kidney disease $(\mathrm{CKD})$ that results from the effects of repeated episodes of red blood cell sickling in patients with SCD. Some of these sickling episodes manifest silently while others occur as painful vaso-occlusive crises. While most obvious in adults with SCD, children also develop significant long-term, permanent, and progressive kidney injury. This injury affects the glomeruli, leading to global or segmental glomerulosclerosis, glomerular hypertrophy, and duplication of the glomerular basement 


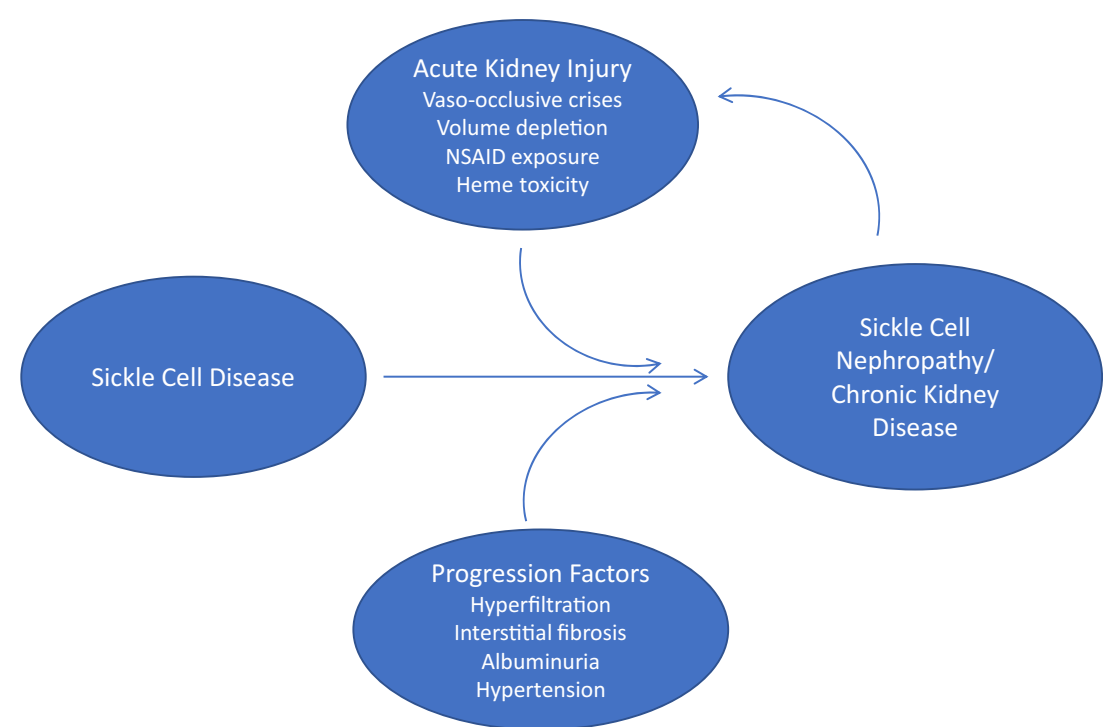

Fig. 1 The putative role of acute kidney injury (AKI) in the progression of sickle cell nephropathy. Progression of chronic kidney disease in sickle cell disease is due to the traditional factors of glomerular hyperfiltration, glomerular hypertrophy and glomerulosclerosis, vascular remodeling, tubular atrophy, and interstitial fibrosis. However, repeated episodes of

membranes, but also results in interstitial fibrosis, tubular atrophy with loss of peritubular capillaries, and papillary necrosis. In fact, renal biopsies in patients and autopsy studies suggest that focal segmental glomerulosclerosis (FSGS) is the most common cause of renal failure in SCD [5]. The medulla is particularly prone to the effects of red blood cell sickling, and vaso-occlusion due to sickling of red blood cells can cause destruction of the vasa recta and loss of peritubular capillaries. The medulla is relatively hypoxic, and the acidic environment and hyperosmolality further increase the intracellular hemoglobin concentration and decrease oxygen affinity, leading to increased red blood cell sickling. These factors ultimately result in impaired blood flow, microinfarctions, and ischemia. Over time, this leads to remodeling of the medullary vasa recta peritubular capillaries with multilayering of the basement membranes, peritubular capillary loss, interstitial fibrosis and tubular atrophy, and papillary necrosis when severe [6-8]. The clinical manifestations of renal medullary injury include hyposthenuria, polyuria, metabolic acidosis, and hyperkalemia.

Hypoperfusion of the medulla results from infarction, thrombosis, and remodeling of the microvasculature, creating a "perfusion paradox" [8]. There is a concomitant increase in cortical blood flow that has damaging consequences, such as glomerular hyperfiltration, enlargement of the glomeruli, tubular hypertrophy, and enlarged kidneys. The endpoint of this hyperfiltration is glomerular scarring with progressive loss of renal function. Glomerular injury is evident in adults with SCD, with up to $50 \%$ of this patient group showing evidence of hyperfiltration and 21-27\% having CKD, defined as an estimated glomerular filtration rate (eGFR) of $<90 \mathrm{~mL} / \mathrm{min} /$ $1.73 \mathrm{~m}^{2}$ [9-12]. The prevalence of end-stage renal disease
AKI, resulting from vaso-occlusive crises, volume depletion due to hyposthenuria, and/or the use of non-steroidal anti-inflammatory drugs (NSAIDS), are likely important contributors to the development and progression of sickle cell nephropathy

(ESRD) in the adult SCD population has been estimated to be between 4 and $12 \%$, with a mean time to ESRD of 37 years $[12,13]$. However, SCD represents only approximately $0.1 \%$ of all incident patients with ESRD in the USA [14].

\section{Sickle cell nephropathy in children}

Sickle cell nephropathy is also apparent in children with SCD, with glomerular hyperfiltration evident as early as infancy. Glomerular hyperfiltration in children was first described decades ago [15] and has since been confirmed in a number of different cohorts [16-18]. In the original study by Etteldorf and colleagues, children with SCD aged 4-11 years had a significantly higher mean measured glomerular filtration rate (mGFR) $\left(169 \mathrm{~mL} / \mathrm{min} / 1.73 \mathrm{~m}^{2}\right)$ than normal controls $\left(128 \mathrm{~mL} / \mathrm{min} / 1.73 \mathrm{~m}^{2}\right)$ [15]. In the BABY HUG trial, a multi-center randomized controlled trial to assess the potential beneficial effects of hydroxyurea in young children with SCD, 176 children aged 9-19 months had a mGFR at baseline of $125 \mathrm{~mL} / \mathrm{min} / 1.73 \mathrm{~m}^{2}$ [16], which was significantly higher than published normal values for the same age group [19]. Interestingly, after 2 years, the mGFR had increased significantly in both the treatment and control groups [17].

Children with SCD may also have evidence of more advanced renal injury, whereby the hyperfiltration, glomerular hypertrophy, and glomerular scarring result in proteinuria. In a cross-sectional study of 410 patients with SCD aged 2-21 (mean age 11) years, 23\% had the HbSS form of SCD, with elevated urinary albumin excretion $(\geq 30 \mathrm{mg} / \mathrm{g})$, while other investigators have reported a HbSS prevalence of $16-27 \%$ in the childhood SCD population [18, 20,21]. 
Further progressive kidney injury and CKD is reflected in a declining and abnormally low GFR. However, data on the prevalence of CKD in childhood SCD are relatively scarce. McPherson Yee reported a CKD (eGFR $\left.<90 \mathrm{ml} / \mathrm{min} / 1.73 \mathrm{~m}^{2}\right)$ prevalence of $12 \%$ of their cohort of 410 children with SCD [22], using serum creatinine and a modified Schwartz formula to calculate eGFR [23]. Similarly, Bodas et al. recently reported a CKD prevalence of $8 \%$ in a cohort of patients with SCD aged 3-17 years, using the same CKD criteria and the same eGFR calculation [24]. The prevalence of ESRD in the pediatric SCD population is also not well described; however, childhood SCD accounts for only $0.3 \%$ of incident pediatric ESRD (U.S. Renal Data System 2015 annual data report; https://www.usrds.org/2015/view). The factors that predispose children with SCD to develop CKD are unknown. As in other kidney diseases, persistently elevated blood pressure and the presence of overt proteinuria likely contribute to progressive glomerular scarring and renal fibrosis leading to secondary FSGS. Pediatric SCD patients with underlying CKD may also be at a higher inherent risk of developing AKI due to inadequate renal reserve.

\section{Sickle cell nephropathy and AKI}

In adults with SCD, AKI has been identified in 4-13.6\% of hospitalized patients and is associated with increased mortality in those admitted to the intensive care unit [25]. Even though there has been a steady growth of AKI literature in pediatric populations over the last decade, little is known regarding the epidemiology of AKI in children with SCD. The recent retrospective study by the Lebensburger group revealed an AKI incidence of $8 \%$ in 149 pediatric patients admitted for acute chest syndrome using the Kidney Disease Improving Global Outcomes (KDIGO) serum creatinine-based definition, and AKI was associated with an increased hospital length of stay [2]. An accompanying article by Baddam and colleagues from the same institution in Alabama (USA) and using the same definition showed that AKI occurred in $17 \%$ of 197 pediatric admissions for pain crisis over a 2-year period and that there was an independent association of AKI with increased length of stay [1].

The true incidence of AKI in pediatric SCD patients may in fact be underestimated from these two retrospective studies [1, 2] due to a lack of available data on baseline serum creatinine in several patients and inconsistent monitoring of creatinine values during admission. In addition, serum creatinine may be an inaccurate marker of GFR in SCD due to the relatively high proximal tubular secretion of creatinine found in this population [26]. Interestingly, a recent adult study showed that even in patients with a normal creatinine level during a pain crisis, acute tubular injury likely occurs, as evidenced by a more than twofold rise in urinary neutrophil gelatinase-associated lipoprotein excretion [27].
The etiology of AKI in the children in these two studies [1, 2] is likely due to a number of causes, such as repeated hypoxic-ischemic episodes to the kidney associated with vasoocclusive crises and, as highlighted by Baddam et al. [1], by higher exposure to NSAIDs. Although the degree of NSAID use at home was difficult to assess due to the retrospective nature of the study [1], the investigators found that the total days and doses of intravenous ketorolac received after admission was associated with the development of AKI. As renal injury progresses in patients with SCD, glomerular perfusion is maintained through compensatory vasodilation and a decrease in renal vascular resistance. These effects are mediated in part through the local production of prostaglandins, which are increased due to medullary ischemia [28]. Studies in adult patients with SCD support a role for prostaglandins in maintaining a normal GFR, as treatment with indomethacin results in a significant decrease in GFR [26, 29]. In addition, NSAID use is common in children with SCD [30], without evidence to support its benefit compared to other less nephrotoxic options [31]. Similarly, the use of NSAIDS in children hospitalized for various other reasons, including dehydration due to gastroenteritis, was associated with a significant increase in the incidence of AKI $[32,33]$. Therefore, it is not surprising that hemodynamic-mediated AKI secondary to NSAIDs, a potential modifiable risk factor, is relatively common in this population, especially as SCD patients are often at higher risk of volume depletion at the time of presentation due to their inherent reduced urine concentrating ability. Another contributing factor includes potential toxic tubular effects of hemoglobin released through hemolysis during a sickle crisis. In children admitted with both vaso-occlusive pain crises and acute chest syndrome, an association was found between a larger drop in hemoglobin and AKI $[1,2]$.

\section{AKI and CKD association}

In adults, a large systematic review and meta-analysis showed that patients with a single episode of AKI had a significantly higher risk of developing CKD and ESRD compared to patients without AKI exposure [34]. In addition, several adult studies have demonstrated a dose-response relationship between $\mathrm{AKI}$ and CKD, including a higher risk of CKD in those with more severe AKI and also in those with repeated episodes of AKI [35-37]. Several pediatric observational studies have also shown a high proportion of CKD in survivors of AKI, ranging from 10 to $69 \%$, but these studies have focused on populations without primary kidney disease [38-44]. Although the etiology of AKI varies in most of these studies, Menon and colleagues identified that nephrotoxic AKI in children increases the risk of CKD at 6 months of follow-up [44]. The contribution of single or repeated episodes of AKI towards the development of CKD specifically in patients with SCD is largely unknown. However, based on the association 
of AKI and CKD found in several adult and pediatric studies to date, there is rationale to suggest a link in SCD patients as well (see Fig. 1). As pointed out, until recently, AKI in patients with SCD has been largely underreported. With a strong signal of AKI coming from smaller retrospective studies, it is evident that larger prospective longitudinal studies in pediatric SCD are needed to properly determine the burden of AKI and to assess how much AKI has a role in the development of early $\mathrm{CKD}$ in this vulnerable population.

\section{References}

1. Baddam S, Aban I, Hilliard L, Howard T, Askenazi D, Lebensburger JD (2017) Acute kidney injury during a pediatric sickle cell vaso-occlusive pain crisis. Pediatr Nephrol. doi:10. 1007/s00467-017-3623-6

2. Lebensburger JD, Palabindela P, Howard TH, Feig DI, Aban I, Askenazi DJ (2016) Prevalence of acute kidney injury during pediatric admissions for acute chest syndrome. Pediatr Nephrol 31: 1363-1368

3. Audard V, Homs S, Habibi A, Galacteros F, Bartolucci P, Godeau B, Renaud B, Levy Y, Grimbert P, Lang P, Brun-Buisson C, Brochard L, Schortgen F, Maitre B, Mekontso Dessap A (2010) Acute kidney injury in sickle patients with painful crisis or acute chest syndrome and its relation to pulmonary hypertension. Nephrol Dial Transplant 25:2524-2529

4. Sklar AH, Perez JC, Harp RJ, Caruana RJ (1990) Acute renal failure in sickle cell anemia. Int J Artif Organs 13:347-351

5. Wesson DE (2002) The initiation and progression of sickle cell nephropathy. Kidney Int 61:2277-2286

6. Statius van Eps LW, Pinedo-Veels C, de Vries GH, de Koning J (1970) Nature of concentrating defect in sickle-cell nephropathy. Microradioangiographic studies Lancet 1:450-452

7. Bissonnette ML, Henriksen KJ, Delaney K, Stankus N, Chang A (2016) Medullary Microvascular thrombosis and injury in sickle hemoglobin C disease. J Am Soc Nephrol 27:1300-1304

8. Nath KA, Hebbel RP (2015) Sickle cell disease: renal manifestations and mechanisms. Nat Rev Nephrol 11:161-171

9. Silva Junior GB, Liborio AB, Vieira AP, Bem AX, Lopes Filho AS, Figueiredo Filho AC, Guedes AL, Souza JH, Costa CM, Costa R, Daher EF (2012) Evaluation of renal function in sickle cell disease patients in Brazil. Braz J Med Biol Res 45:652-655

10. Guasch A, Navarrete J, Nass K, Zayas CF (2006) Glomerular involvement in adults with sickle cell hemoglobinopathies: prevalence and clinical correlates of progressive renal failure. J Am Soc Nephrol 17:2228-2235

11. Gosmanova EO, Zaidi S, Wan JY, Adams-Graves PE (2014) Prevalence and progression of chronic kidney disease in adult patients with sickle cell disease. J Investig Med 62:804-807

12. Powars DR, Elliott-Mills DD, Chan L, Niland J, Hiti AL, Opas LM, Johnson C (1991) Chronic renal failure in sickle cell disease: risk factors, clinical course, and mortality. Ann Intern Med 115:614620

13. Powars DR, Chan LS, Hiti A, Ramicone E, Johnson C (2005) Outcome of sickle cell anemia: a 4-decade observational study of 1056 patients. Medicine 84:363-376

14. Abbott KC, Hypolite IO, Agodoa LY (2002) Sickle cell nephropathy at end-stage renal disease in the United States: patient characteristics and survival. Clin Nephrol 58:9-15
15. Etteldorf JN, Tuttle AW, Clayton GW (1952) Renal function studies in pediatrics. 1. Renal hemodynamics in children with sickle cell anemia. Am J Dis Child 83:185-191

16. Ware RE, Rees RC, Sarnaik SA, Iyer RV, Alvarez OA, Casella JF, Shulkin BL, Shalaby-Rana E, Strife CF, Miller JH, Lane PA, Wang WC, Miller ST, Investigators BABYHUG (2010) Renal function in infants with sickle cell anemia: baseline data from the BABY HUG trial. J Pediatr 156:66-70

17. Alvarez O, Miller ST, Wang WC, Luo Z, McCarville MB, Schwartz GJ, Thompson B, Howard T, Iyer RV, Rana SR, Rogers ZR, Sarnaik SA, Thornburg CD, Ware RE, Investigators BABYHUG (2012) Effect of hydroxyurea treatment on renal function parameters: results from the multi-center placebo-controlled BABY HUG clinical trial for infants with sickle cell anemia. Pediatr Blood Cancer 59:668-674

18. Becker AM (2011) Sickle cell nephropathy: challenging the conventional wisdom. Pediatr Nephrol 26:2099-2109

19. Piepsz A, Tondeur M, Ham H (2006) Revisiting normal (51)Crethylenediaminetetraacetic acid clearance values in children. Eur J Nucl Med Mol Imaging 33:1477-1482

20. Alvarez O, Montane B, Lopez G, Wilkinson J, Miller T (2006) Early blood transfusions protect against microalbuminuria in children with sickle cell disease. Pediatr Blood Cancer 47:71-76

21. Dharnidharka VR, Dabbagh S, Atiyeh B, Simpson P, Sarnaik S (1998) Prevalence of microalbuminuria in children with sickle cell disease. Pediatr Nephrol 12:475-478

22. McPherson Yee M, Jabbar SF, Osunkwo I, Clement L, Lane PA, Eckman JR, Guasch A (2011) Chronic kidney disease and albuminuria in children with sickle cell disease. Clin J Am Soc Nephrol 6: 2628-2633

23. Schwartz GJ, Munoz A, Schneider MF, Mak RH, Kaskel F, Warady BA, Furth SL (2009) New equations to estimate GFR in children with CKD. J Am Soc Nephrol 20:629-637

24. Bodas P, Huang A, O'Riordan MA, Sedor JR, Dell KM (2013) The prevalence of hypertension and abnormal kidney function in children with sickle cell disease - a cross sectional review. BMC Nephrol 14:237

25. Cecchini J, Lionnet F, Djibre M, Parrot A, Stojanovic KS, Girot R, Fartoukh M (2014) Outcomes of adult patients with sickle cell disease admitted to the ICU: a case series. Crit Care Med 42: $1629-1639$

26. de Jong PE, de Jong-Van Den Berg TW, Sewrajsingh GS, Schouten H, Donker AJ, Statius van Eps LW (1980) The influence of indomethacin on renal haemodynamics in sickle cell anaemia. Clin Sci 59:245-250

27. Audard V, Moutereau S, Vandemelebrouck G, Habibi A, Khellaf M, Grimbert P, Levy Y, Loric S, Renaud B, Lang P, Godeau B, Galacteros F, Bartolucci P (2014) First evidence of subclinical renal tubular injury during sickle-cell crisis. Orphanet J Rare Dis 9:67

28. de Jong PE, Statius van Eps LW (1985) Sickle cell nephropathy: new insights into its pathophysiology. Kidney Int 27:711-717

29. Allon M, Lawson L, Eckman JR, Delaney V, Bourke E (1988) Effects of nonsteroidal antiinflammatory drugs on renal function in sickle cell anemia. Kidney Int 34:500-506

30. Cacciotti C, Vaiselbuh S, Romanos-Sirakis E (2016) Pain Management for Sickle Cell Disease in the pediatric emergency Department: medications and hospitalization trends. Clin Pediatr (Phila). doi:10.1177/0009922816674521

31. Hardwick WE Jr, Givens TG, Monroe KW, King WD, Lawley D (1999) Effect of ketorolac in pediatric sickle cell vaso-occlusive pain crisis. Pediatr Emerg Care 15:179-182

32. Balestracci A, Ezquer M, Elmo ME, Molini A, Thorel C, Torrents M, Toledo I (2015) Ibuprofen-associated acute kidney injury in dehydrated children with acute gastroenteritis. Pediatr Nephrol 30: $1873-1878$ 
33. Misurac JM, Knoderer CA, Leiser JD, Nailescu C, Wilson AC, Andreoli SP (2013) Nonsteroidal anti-inflammatory drugs are an important cause of acute kidney injury in children. J Pediatr 162: $1153-1159$

34. Coca SG, Singanamala S, Parikh CR (2012) Chronic kidney disease after acute kidney injury: a systematic review and meta-analysis. Kidney Int 81:442-448

35. Chawla LS, Amdur RL, Amodeo S, Kimmel PL, Palant CE (2011) The severity of acute kidney injury predicts progression to chronic kidney disease. Kidney Int 79:1361-1369

36. Ishani A, Xue JL, Himmelfarb J, Eggers PW, Kimmel PL, Molitoris BA, Collins AJ (2009) Acute kidney injury increases risk of ESRD among elderly. J Am Soc Nephrol 20:223-228

37. Thakar CV, Christianson A, Himmelfarb J, Leonard AC (2011) Acute kidney injury episodes and chronic kidney disease risk in diabetes mellitus. Clin J Am Soc Nephrol 6:2567-2572

38. Mammen C, Al Abbas A, Skippen P, Nadel H, Levine D, Collet JP, Matsell DG (2012) Long-term risk of CKD in children surviving episodes of acute kidney injury in the intensive care unit: a prospective cohort study. Am J Kidney Dis 59:523-530
39. Viaud M, Llanas B, Harambat J (2012) Renal outcome in long-term survivors from severe acute kidney injury in childhood. Pediatr Nephrol 27:151-152, author reply 153

40. Slack R, Hawkins KC, Gilhooley L, Addison GM, Lewis MA, Webb NJ (2005) Long-term outcome of meningococcal sepsis-associated acute renal failure. Pediatr Crit Care Med 6: 477-479

41. Shaw NJ, Brocklebank JT, Dickinson DF, Wilson N, Walker DR (1991) Long-term outcome for children with acute renal failure following cardiac surgery. Int J Cardiol 31:161-165

42. Georgaki-Angelaki HN, Steed DB, Chantler C, Haycock GB (1989) Renal function following acute renal failure in childhood: a long term follow-up study. Kidney Int 35:84-89

43. Askenazi DJ, Feig DI, Graham NM, Hui-Stickle S, Goldstein SL (2006) 3-5 year longitudinal follow-up of pediatric patients after acute renal failure. Kidney Int 69:184-189

44. Menon S, Kirkendall ES, Nguyen H, Goldstein SL (2014) Acute kidney injury associated with high nephrotoxic medication exposure leads to chronic kidney disease after 6 months. J Pediatr 165: $522-527$ 